\title{
QUESTIONING THE THEORY AND PRACTICE OF BIOMIMICRY
}

\author{
A. MARSHALL ${ }^{1} \&$ S. LOZEVA ${ }^{2}$ \\ ${ }^{1}$ Curtin University Research Centre for Stronger Communities, Australia. \\ ${ }^{2}$ Curtin University Sustainability Policy Institute, Australia.
}

\begin{abstract}
Gaining inspiration from nature has a new name: biomimicry. As a supposedly novel technical practice, biomimicry makes promises about solving the world's technological problems and environmental problems simultaneously. After posing questions about the features, assumptions and ambitions of biomimicry, it is concluded that biomimicry might be a productive way to render nature's secrets available for commercial and industrial purposes, but for it to move society towards eco-friendliness as it's supporters often claim, they will have to actively reconstruct the concept with the help from ecocentric ideas.
\end{abstract}

Keywords: biomimicry, eco-friendliness, ecomimicry, nature.

\section{WHAT IS BIOMIMICRY?}

The idea of mimesis (to imitate) comes from the Greek concept mīmos, which means the representation of aspects of the real world, especially in human actions. (In literature and art, though, it is used in this sense; as representation, rather than copying [1].) Mimicry is a term derived from mimesis and it is used in the sense to mean the act or the ability to simulate the appearance of someone or something else. Both Plato and Aristotle understood mimesis as the representation of nature [2].

The more recent term 'biomimicry' has been popularised by Janine Benyus [3] in her book Biomimicry: Innovation Inspired by Nature. On the cover of this book, biomimicry is referred to as 'a revolutionary new science that analyses nature's best ideas and adapts them for human use'. This means the goal is to translate biological processes into technologies not by using biological materials but by emulating biological examples either in the lab or on site. Those engaged in biomimicry regard the structure and function of many biological processes as being 'far superior' [4] to the technologies humans have yet designed.

For self-declared biomimics though [3-5] there is an ongoing attempt to 'harden' biomimicry into a formalised discipline or a specific design method. This formalisation is at an adolescent stage, but this does not halt the characteristic hyperbole associated with invention of new technological disciplines, for example:

By treating nature as 'model, measure and mentor' ... companies, governments and universities are in a strong position to take advantage of the leading edge opportunities provided by the emerging field of $\ldots$ biomimicry [6].

We now stand at the advent of a revolution that will change the way we conceive, design and construct buildings [7].

The field of biomimetics, the application of methods and systems found in nature to engineering and technology, has spawned a number of innovations far superior to what the human mind alone could have devised [8].

It has to be pointed out that the label biomimicry is competing with the label 'biomimetics' as the name of the professional practice of bio-inspired design. The former label is the construct of the 
American inventor Otto Schmitt. Those who register this debt prefer the term biomimetics, but largely the two terms are used in the research literature synonymously and this is the way I shall treat them.

\section{IS BIOMIMICRY ALL THAT NEW?}

The answer to this question is 'Yes and No'. 'No' because numerous historical examples can easily be cited of bio-inspired design:

1. Indigenous management of landscapes that mimicked natural processes $[9,10]$.

2. Leonardo Da Vinci's bird-like flying machine designs [11].

3. Some of the 19th century architectural ideas of Gottfried Semper who worked with the anatomical studies of renowned French naturalist George Cuvier [12].

4. The turn-of-the-century biomorphic style of Art Nouveau [13].

5. George de Mistrals invention of Velcro based upon the attachment properties of cockle burs [14].

The question might be answered 'Yes' because practicing biomimics state they are

1. Formulating precise methodologies of bio-inspiration and innovation, rather than occasional application of serendipitous analogies/discoveries [15-17].

2. Working with new modern scientific knowledge which vastly outclasses that available to previous designers [3].

3. Going beyond the mere shape of creatures (biomorphia) to look at the functions their bodies perform both in and of themselves (and within their ecosystem) [3].

This last part might not be that significant, though, since shape is often an essential part of in enabling organs and organisms to function well in their environment.

Given the above background of biomimicry, it might be suggested that the term is just a new label for all sorts of established practices, like for instance bionics (a biomedical practice which seeks to emulate human organs), permaculture (an agricultural practice that aims to emulate native grasslands and bushlands) and analogue forestry (a forestry practice that aims to emulate natural forests). Thus, for some, biomimicry could be regarded as an organising concept rather than a novel method of design.

\section{IS BIOMIMICRY INHERENTLY SUSTAINABLE?}

According to many of its proponents, the process of biomimicry will do two things:

1. enable humans to avail themselves of some really novel technologies and

2. provide these really novel technologies in an inherently sustainable way

The technological products and processes that biomimicry lead to will not only make industrial and domestic life easier, it is said they will also care for the environment in a positive way.

While Benyus [3] comes across quite strongly about the supposed eco-friendly nature of biomimicry, this is not always how the practice of biomimicry unfolds. If we study what practitioners of biomimicry actually do, it seems that point 1 listed above is far more significant than point 2 . For instance, if we take a short trip through some recent research projects in biomimicry, we find projects devoted to:

- designing undetectable surveillance cameras based on the compound eyes of insects [18, 19].

- emulating biological molecules, such as DNA, to create industrial nanomachines [20, 21]. 
- exploring other planets with space craft inspired by insects, spiders and worms[22, 23].

- inventing new military technologies based on all kinds of animals and plants [8, 24].

- fashioning new consumer bio-inspired products (from bionic automobiles [25] to geneticallyengineered fibres [26]).

None of these projects has pronounced sustainability credentials. Some probably involve expanded ecological footprints and others a high degree of environmental risk. It is also noteworthy that the prime funders of large-scale biomimicry research are tending to be the defence industry along with various large corporations. What this suggests is that biomimicry could indeed be a profitable way to render nature's secrets available for human use, but it is a tool with as much capacity for environmental harm as for eco-friendliness.

\section{BIOMIMICRY AS A TECHNOCENTRIC IDEA}

The belief that techno-fixes are the path to global eco-friendliness has been labelled 'technocentrism'. Various writers define technocentrism in slightly different ways [27], but generally technocentrism is held to involve ideas such as the following:

- economic growth and technological growth hold the key to solving ecological and social problems

- science is able to provide precise and politically neutral information for the management of the environment

- an anthropocentric value system (humans are the locus of ultimate value; nature is a resource for humanity)

- the role of experts (scientists, engineers and technocrats) is venerated and privileged

- the market is the best conduit for realising technological dispersal across society

- globalisation and the universality of mass-produced technology is a force for good

- centralised organisation of technological development (in the hands of a few corporations and Governments) is both normal and efficient

- the spirit of industrialism should be encouraged

In contrast to technocentrism lies ecocentrism, which-as it name suggests- espouses values centred around 'ecology' rather than 'technology' [28, 29]. Ecocentrism tends to be:

- pessimistic about the chances that science and technology alone will save the world from environmental crisis

- wary about the virtues of centralised decision making and the (biased) knowledge of experts

- supportive of technological innovations that are low intensity, people-oriented, sustainable, democratic, and do not require its users to become trapped in a global market system

- non-anthropocentric (humans are not the only locus of ultimate value; nature is to be preserved because it, too, has intrinsic value).

If technocentrism means values centred on technology and ecocentrism means values centred on ecology, then, in a philosophical sense, it is possible to interpret biomimicry as potentially bridging the two philosophies since it involves the creation of technology that values nature. In practice, though, biomimicry (as put into action by projects like biomimetic fibres, bionic cars, interplanetary spacecraft, new military hardware etc) does not value nature intrinsically but instrumentally as a resource (in particular as a supplier of useful information). 
We might also judge that the biomimicked projects listed above cannot possibly be ecocentric given their propensity to:

- propose technological solutions to problems that can be handled in other ways (spiritual, social, political, behavioural, moral ways, for instance)

- expand unsustainable practices and industry

- favour the market as the main dispersal mode (and converting all citizens into mere consumers)

- rely on science as the best (and only truth-exposing) medium to interpret nature (instead of through other realms of human thought such as religion, poetry, philosophy and politics)

- embed local communities in a global technology trap (where they are promised personal freedom and flexibility through technology but soon become dependent on faraway resources and experts)

For some biomimicked solutions, the charge that biomimicry is technocentric does a disservice. For example, research on perennial agriculture [30] and bio-inspired passive cooling [7].

Benyus, perhaps one of the Greenest voices in biomimicry, is also attempting to publicise the notion of 'giving thanks' to organisms that serve to inspire human innovations [3]. Although this can be criticised as a tokenistic solution to the systemic problem of wilderness destruction, it can be construed as an attempt to value nature intrinsically instead of just instrumentally (and thus act as an avenue for ecocentrism to infiltrate biomimicry). The works of other biomimics, though, do not tend to show such respect for nature. Instead, they focus on the way humans can derive benefits from it.

One might believe imitation to be the greatest compliment. If so then are we complimenting nature when we seek to emulate her? In one way, biomimics are paying homage to the ingenuity of nature, admitting that nature has solved some generic physical problems better than human designers have. At the same time, though, the practice of biomimicry seems to show deep disrespect to nature, 'stealing ideas from nature' [31] in a manner that borders on biopiracy [32]. If nature has four billion years of research and development waiting to be tapped into, as the biomimics like to sloganeer, then do we not instantaneously objectify the members of the ecological community into mere intellectual resources through biomimicry (rather than regarding them as subjects worthy of interaction, care and respect? [33])

\section{WHAT DOES IT MEAN TO MIMIC NATURE?}

Nature is a big thing, both physically and conceptually. There are many levels within it that may serve as a basis for bio-inspiration: from the molecular level, through the organismal level to the ecosystem and biosphere levels. There is also a lot going on in nature: birth, death, sex, cooperation, competition, parasitism, predation, scavenging, nurturing and care, movement and mechanics, cycling and recycling, growth and decay, etc. Some of these processes appear quite amazing and wonderful to us humans. Some of it appears wasteful and cruel. Philosophical reflection upon the great diversity of processes in nature might lead one to regard it as so riddled with self-contradictory diversity that it is impossible to extract any general principles from it. For all the examples we may give where nature seems dynamic and energetic, for instance, there are plenty of examples that show it to be sluggish and degenerative.

Despite the amazing diversity of nature, Benyus [3] believes it is important for biomimics to take account of certain basic laws of nature when they engage in the practice of biomimicry. For her, there are nine such basic laws:

1. Nature runs on sunlight

2. Nature uses only the energy it needs 
3. Nature fits form to function

4. Nature recycles everything (finding a use for all wastes)

5. Nature rewards cooperation

6. Nature banks on diversity

7. Nature demands local expertise

8. Nature curbs excesses from within

9. Nature taps the power of limits

Critics from a positivist slant (whereby it is held that true knowledge about nature is obtainable if you use the correct methods) would surely like to point out that all these basic laws of nature are broken by nature herself. For instance, with regards to number 7, there are generalist organisms that rove around wildly different geographic regions with no great adaptations to local situations, yet they still thrive. Similarly with regard to number 1, some organisms deep in the ocean feed within ecosystems totally removed from the impact of solar radiation. From this point of view, there may be a problem in practicing biomimicry based on any 'basic law of nature' since what is or is not a basic law of nature is entirely contestable. Nature, at least biological nature, is just too diverse to be generalisable into laws.

Critics from a constructionist slant (whereby the secrets of nature are believed constructed through human-human negotiations rather than revealed by them) would suggest that these 'laws of nature' have been projected on to Nature by Benyus because she feels they reflect worthy or workable goals and values (from both a technical and philosophical perspective). Other biomimics-in a project to strengthen the focus of biomimicry-have also been engaged in relating what they see as basic laws of nature worth mimicking; Stach [34] indicating 'self-organisation is the defining principle of nature', for example, and Faludi [35] indicating that fractal organisation and self-assembly are 'general principles in nature'. Various constructionist reactions to these proffered laws of nature offered by biomimics might be:

1. Do not trust the laws of nature espoused by biomimics since they are filtered through the values and politics of those that espouse them and so are mere delusions.

2. Do not trust the laws of nature espoused by biomimics since they are filtered through the values and politics of those that espouse them and may well be ideologically distasteful (the ideological danger of naturalistic mimicking can be observed, for instance, when idealogues say that the functioning of ecosystems proves this or that social system is the natural-and best-form of human social organisation).

3. Interpret the laws of nature espoused by biomimics with a grain of salt as myths and metaphors that serve some purpose but judge them by that purpose and by the politics and values they espouse rather than their claimed authority from nature. From this perspective, although we know that the laws of nature are myths and metaphors, they might actually work to make the world a better place if the values within them compliment social and ecological welfare.

If you approach biomimicry from a positivist slant, believing at least some of our knowledge about nature reflects true reality, then at some point you are going to have to wrestle with what nature actually is. In our professional lives, scientists, technologists, designers and philosophers struggle to codify the term 'nature'.

Depending on what particular rhetorical struggle we might be engaged with at any one moment:

1. Nature may be everything that is, excluding humans or God 
2. Nature may be everything that ever is, including humans and God

3. Nature maybe everything that did not come about by human artifice. So human bodies may indeed be natural, but the things we make with our hands and minds are artificial.

Mapped on top of this we also have ideas that nature may be discrete living things (bugs, birches, birds and buffalo, for instance) or discreet non-living things (rocks, rivers, oceans, stars and planets). Nature may also be indiscreet processes (evolution, self-generation, homeostasis, natural selection, etc.).

Given the diverse categories of things that are natural and given the diverse principles that we ascribe to nature, it is likely we act both in accordance with nature and against it at the same moment. Thus, we might be said to be mimicking nature when we share resources in a cooperative manner since this is what various parts of nature happen to do (penguins form social crèches to take care of their young, bacteria cooperate symbiotically with trees to provide nitrogen etc.). Also, though, we might be said to be mimicking nature when we fight and compete for resources since parts of nature are said to be 'Red in Tooth and Claw' (for instance when predators stalk their prey or when plants push and shove each other in a struggle for space and light).

Given this, there is ample space for intellectual contest over what nature is trying to teach us. Philosophers have often resorted to the 'is-ought' problem [36] when reflecting on these tensions (stating that what 'ought' to be done does not logically follow from what 'is' in nature), but biomimics have not got this luxury since they are advocating that what 'is' in nature ought to be mimicked in the technological and industrial world of humans.

If the concept 'nature' is slippery within the field of biomimicry, then so is the concept of 'mimicry'. Mimicry means imitating something, but biomimics admit that their not really involved in imitation per se but in emulation. Thus, what they are doing is not copying but gaining insights that might be of use. Benyus [3] would sum it up by saying that nature should be regarded as our teacher. By this reckoning, nature can guide us towards developing our own solutions.

When contemplating nature as a teacher, it soon becomes clear that nature can be thought of as a teacher in two main ways:

- as a teacher of values and morals (in which case we can be guided by nature in what Rolston [37] says is in an 'imitative ethical sense')

- as a technical advisor (in which we follow nature in tutorial manner [37])

Most biomimics would probably want to suggest that the technical part is the main preserve of biomimicry and this might well apply to Janine Benyus as well. For all her talk of nature's wisdom, and the need to respect it, she spends most of her Biomimicry book remarking upon the need for humans to adopt the amazing 'technologies of nature'.

According to a number of workers on the social studies of both nature [38-40] and technology [41-43], it is nigh on impossible to have:

1. stories about nature without values embedded in them

2. technologies without values embedded in them

This means that the practice of biomimicry would have a double set of values as it goes about its bio-inspired designs. On this score, also, any biomimicked product that is said to mimic a certain natural phenomena or object will necessarily be replete with two (and probably more) sets of values. Technical advice gleaned from nature will contain a cocktail of undeclared values. The exact mix of 
values for any biomimicked technology will probably be unique to that technology and require intensive study to identify but as cursory examples consider the following three suggestions:

1. Permaculture is a form of biomimicry that mimics natural ecosystems for agricultural purposes. It is thus a riddled with a whole bunch of values related to challenging industrial farming, celebrating local resource use and the promotion of better eating, communalism and stepping lightly on the environment. The permaculturalists have a whole litany of openly declared philosophical principles that they believe accompany the practice of permaculture $[44,45]$ from 'preserving natural balance' to 'intergenerational ethics'.

2. Space biomimicry is a field that attempts to learn techniques from animals and plants that will be useful in space projects $[22,46]$. The values within such research, of which NASA and the European Space Agency are key sponsors, imply that space development and colonisation is a good thing and that public investment in big science projects (with minimal social return) is a worthy way to spend taxpayer funds.

3. Industrial Ecology is a form of biomimicry that tries to mimic natural ecosystems in an industrial setting. The idea is to mimic the processes going on in nature, for instance, recycling of waste materials. The values of such an ambitious project reflect the idea that industrialism can, and ought to be, made more eco-friendly and that technical expertise in translating (either figuratively or literally) the patterns of ecosystems is the way to do this. Since the precise notion of nature that industrial ecologists use is a 'system', the goal of preserving the system rather than its members (be they species or people) is the implicit validated result.

\section{CONCLUSIONS: SHOULD WE EXPECT MORE FROM BIOMIMICRY?}

As an intellectual movement in design and innovation, biomimicry might indeed offer a way to transform new technological patterns. However, for it to do so in a sustainable manner, I believe it needs more than a little tweaking. If biomimicry can learn from various ecocentric traditions, such as the alternative technology and Deep Ecology movements, then it can be transformed into a more manifestly environmental practice. We can deem this alternative approach 'ecomimicry', the mimicking of nature for eco-friendly design.

Whereas biomimicry (a) does not necessarily involve eco-friendly technological design, (b) is invented and regulated by experts and (c) works within the mass market without much democratic input, ecomimicry will operate to be:

- inherently sustainable from an environmental and social point of view

- encouraging of decentralisation and localism

- democratic when it comes to decision making over technological change

- understood by all, not just by the experts

- sensitive to the need to disperse power rather than to concentrate it

All these suggestions work within the social dimension of design and can be woven into the practice of bio-inspired design in order to synergistically get the most out of human communities as well as biotic communities. This is explained in more detail in Table 1.

The introduction of the label ecomimicry is not intended as a launch of a grand new philosophy and practice of technology, it merely acts as a categorisation system that delineates between practices of mimicking nature that are not particularly socially and environmentally responsible (biomimicry) and practices of mimicking nature that aim to be environmentally sensitive and socially just (ecomimicry). 
Table 1: Characteristics of biomimicry and ecomimicry (adapted from Ryn and Cowan's categories of ecodesign [47]).

\begin{tabular}{|c|c|c|}
\hline & Biomimicry & Ecomimicry \\
\hline Energy source & $\begin{array}{l}\text { Usually not renewable, local, } \\
\text { decentralised and small scale }\end{array}$ & $\begin{array}{l}\text { Always renewable, localised, } \\
\text { decentralised and small scale }\end{array}$ \\
\hline Materials used & May be toxic and sourced from afar & $\begin{array}{l}\text { Never toxic and always locally } \\
\text { sourced }\end{array}$ \\
\hline Pollution & May be minimal or may be extensive & Always negligible or degradable \\
\hline Sustainability & $\begin{array}{l}\text { May be environmentally responsible } \\
\text { but more likely to be environmentally } \\
\text { harmful or risky }\end{array}$ & $\begin{array}{l}\text { Only included innovations } \\
\text { contributing to the welfare of the } \\
\text { environment }\end{array}$ \\
\hline Design criteria & $\begin{array}{l}\text { Functionality within current } \\
\text { engineering and commercial } \\
\text { systems is main priority }\end{array}$ & $\begin{array}{l}\text { Contributes to environmental } \\
\text { protection or betterment or has } \\
\text { near zero ecological footprint }\end{array}$ \\
\hline $\begin{array}{l}\text { Ecological } \\
\text { sensitivity }\end{array}$ & $\begin{array}{l}\text { Biomimicked designs may or may } \\
\text { not be ecologically sensitive }\end{array}$ & Always ecologically sensitive \\
\hline Social sensitivity & $\begin{array}{l}\text { Based on present social system } \\
\text { which includes lack of concern } \\
\text { for social betterment of most local } \\
\text { communities }\end{array}$ & $\begin{array}{l}\text { Socially responsible and aware of the } \\
\text { need to protect and encourage local } \\
\text { communities in the global system }\end{array}$ \\
\hline Values nature & $\begin{array}{l}\text { Values nature as an intellectual } \\
\text { resource }\end{array}$ & $\begin{array}{l}\text { Values nature as a collection of } \\
\text { intrinsically important creatures } \\
\text { and life forms }\end{array}$ \\
\hline Civic participation & $\begin{array}{l}\text { Relies on recognised established } \\
\text { experts from science, design and } \\
\text { engineering and project } \\
\text { management }\end{array}$ & $\begin{array}{l}\text { Technology and decision making are } \\
\text { more fairly distributed; innovations } \\
\text { and techno-decisions come from } \\
\text { bottom up }\end{array}$ \\
\hline $\begin{array}{l}\text { Role of } \\
\text { Government }\end{array}$ & $\begin{array}{l}\text { Gives taxpayer money to large } \\
\text { corporations and government sectors } \\
\text { via subsidies, large R\&D grants or } \\
\text { tax incentives; defines regulations and } \\
\text { imposes centralised uniform solution }\end{array}$ & $\begin{array}{l}\text { Allows communities to organise } \\
\text { their own technological future by } \\
\text { funding small-scale project; does not } \\
\text { impose centralised solution }\end{array}$ \\
\hline Funding & $\begin{array}{l}\text { Large-scale defence industry along with } \\
\text { various large corporations }\end{array}$ & $\begin{array}{l}\text { Community based (with self-funding } \\
\text { schemes and novel use of centralised } \\
\text { funding) }\end{array}$ \\
\hline Political power & $\begin{array}{l}\text { Gathers it in traditional places } \\
\text { (governments, corporations and } \\
\text { professional elite), thus encouraging } \\
\text { geographical and class-like injustices }\end{array}$ & $\begin{array}{l}\text { Disperses it to communities, } \\
\text { individuals, creative groups, } \\
\text { households and neighbourhoods }\end{array}$ \\
\hline
\end{tabular}


If we accept this new label, then it might readily apply to some of the biomimetic solutions that Benyus and others have nominated as sustainable bio-inspired technologies. However, there is little chance a mass-produced car or jet can claim to be an example of ecomimicry, nor many of the other examples listed above in this paper. Plenty of biomimics will respond that although biomimicry may like to prudently protect the environment so that it can remain a source for innovative ideas, there is no requirement that bio-inspired technologies must necessarily do this. For such people, I would suggest they keep using the term biomimicry instead of ecomimicry to describe their work.

\section{REFERENCES}

[1] Gebauer, G. \& Wulf, C., Mimesis: Culture - Art - Society Trans. Don Reneau, University of California Press: Berkeley and London, 1992.

[2] Davis, M., The Poetry of Philosophy - On Aristotle's Poetics, St Augustine's Press, 1999.

[3] Benyus, J., Biomimicry: Innovation Inspired by Nature, PerennialHarper, 2002.

[4] Bar-Cohen, J., Biomimetics: Biologically Inspired Technologies, CRC Press, 2005.

[5] Vincent, J., Design in nature. Optimisation Mechanics in Nature, eds M. Collins, G. Hunt \& M.A. Atherton, WIT Press: Southampton, pp. 145-54, 2004.

[6] Hargroves, K. \& Smith, M.H., Innovation inspired by nature: biomimicry. ECOS Magazine, 129, pp. 27-29, 2006.

[7] Koelman, O., Building the future of buildings. BioInspire, 20, September 2004.

[8] Butler, R., Biomimetics, technology that mimics nature. MongaBayNews, 2005.

[9] Freeman, M.M.R. \& Carbyne, L., Traditional Knowledge and Renewable Resource Management in Northern Regions, Boreal Institute, University of Edmonton, 1988.

[10] Seeland, K., Nature is Culture: Indigenous Knowledge and Socio-Cultural Aspects of trees and Forests in Non-European Cultures, Intermediate Technology Publishing Group, 1997.

[11] Laurenza, D., Tadei, M. \&. Zenon, E., Leonardo's Machines: Da Vinci's Inventions Revealed, David and Charles Publishers, 2006.

[12] Aldersley-Williams, H., Zoomorphic: A New Animal Archietcure, 2003.

[13] Greenhalgh, P., Art Nouveau 1890-1914, Harry N Abrams Publishers, 2000.

[14] Pareti, C., Extraordinary Origins of Everyday Things, Harper, 1989.

[15] Biomimicry Guild, 2008; available from: http://www.biomimicry.net/guildFrame.html.

[16] Waterhouse, G., The biomimetic method in industrial design. Design for Sustainability, ed. J. Birkeland,Earthscan: London, pp. 84-89, 2002.

[17] Alves, N.M.F. \& Bartolo, P.J.S, Advanced reverse design through a new biologically based system. Design and Nature II: Comparing Science and Engineering, eds M.W. Collins \& C.A. Brebbia, WIT Press, 2004.

[18] Duparre, J.W. \& Wippermann, F.C., Micro-optical artficial compound eyes. Bioinspiration and Biomimetics, 1(1), pp. R1-R16, 2006.

[19] Toko, K., Biomimetic Sensor Technology, Cambridge University Press: Cambridge, 2005.

[20] Lerner, E.J., Biomimetic nanotechnology. Industrial Physicist, August/September, pp. 16-19, 2004.

[21] Martin, D., Nanobiotechnology of Biomimetic Membranes, Springer, 2006.

[22] Ayre, M., Biomimetics applied to space exploration. Design and Nature II: Comparing Science and Engineering, eds M.W. Collins \& C.A. Brebbia, WIT Press, pp. 603-612, 2004.

[23] Thakoor, S., Insectile and vermtform exploratory robots. NASA Technical Brief, 23(11), pp. 1-22, 1999.

[24] Forbes, P., Eluding the enemy. The Guardian, January 16, 2003.

[25] Mercedes, The Mercedes Benz Bionic Car, Mercedes Benz Press Kit, 2005. 
[26] Teule, F., Biomimetic manufacturing of fibers. Design and Nature II: Comparing Science and Engineering, eds M.W. Collins \& C.A. Brebbia, WIT Press, pp. 483-491, 2004.

[27] Eckersley, R., Environmentalism and Political Theory: Toward an Ecocentric Approach, State University of New York Press, 1992.

[28] Drengson, A., The Practice of Technology: Exploring Technology, Ecophilosophy, and Spiritual Disciplines for Vital Links, SUNY Press: Albany, 1995.

[29] Breen, S.D., Ecocentrism, weighted interests and property theory. Environmental Politics, 10(1), pp. 36-51, 2001.

[30] Cox, T.S., et al., Prospects for developing perennial grains. BioScience, 56(8), pp. 649-659, 2006.

[31] Vincent, J., Stealing ideas from nature. Deployable Structures, ed. S. Pellegrino, Springer: Vienna, pp. 51-58, 2002.

[32] Shiva, V., Biopiracy: The Plunder of Nature and Knowledge, South End Press, 1997.

[33] Warren, K., Ecological Feminist Philosophies, A Hypatia book, University Press: Bloomington, IN, 1996.

[34] Stach, E., Form-optimizing processes in biological structures - self-generating structures in nature based pneumatics. Design and Nature II: Comparing Science and Engineering, eds M.W. Collins \& C.A. Brebbia, WIT Press, pp. 3-24, 2004.

[35] Faludi, J., Biomimicry for green design (a how to). WorldChanging.com, pp. 1-11, 2005.

[36] Schuuz, G., The Is-Ought Problem - An Investigation, Philosophical Logic Kluwer: Dordrecht, 1997.

[37] Rolston, H.I., Can and ought we follow nature? Environmental Ethics, 1, pp. 7-30, 1979.

[38] Mirowski, P., Natural Images in Economic Thought: Markets Read in Tooth and Claw, Cambridge University Press, 1994.

[39] Horigan, S., Nature and Culture in Western Discourses, Routledge: London, 1998.

[40] Marshall, A., The Unity of Nature: Wholeness and Disintegration in Ecology and Science, Imperial College Press: London, 2002.

[41] Winner, L., The Whale and the Reactor: A Search for Limits in an Age of High Technology, The University of Chicago Press: Chicago, 1986.

[42] Mayr, O., Authority, Liberty and Automatic Machinery in Early Modern Europe, Johns Hopkins University Press: Baltimore, 1989.

[43] Mitcham, C., Thinking Through Technology: The Path between Engineering and Philosophy, The University of Chicago Press: Chicago, 1994.

[44] Holmgren, D., The Permaculture Way: Practical Steps to Creating a Self-Sustaining World, Holmgren Associates, 2002.

[45] Hemenway, T., Gaia's Garden: A Guide to Homse-Scale Permaculture, Chelsea Green Publishers, 2001.

[46] Siochi, E.J., et al., Biomimetics for NASA, NASA/TM-2002-211445, 2002.

[47] Ryn, S.V.d. \& Cowan, S., Ecological Design, Island Press: Washington, DC, 2007. 